\title{
Commentary on "the middle fossa approach with self-drilling screws: a novel technique for BONEBRIDGE implantation"
}

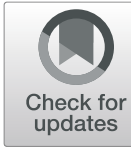

\author{
C. Carnevale* (D, M. Tomás-Barberán, G. Til-Pérez, E. Enchev and P. Sarría-Echegaray
}

To the Editor:

We read with great interest the article titled "The middle fossa approach with self-drilling screws: a novel technique for BONEBRIDGE implantation" by You et al. [1]. In this study with 40 patients, the authors concluded that middle fossa approach with self drilling screws is a safe alternative to Bonebridge implantation, with no complications after an average follow up of 29 months. We consider that this study is properly conducted and highlights many of the benefits of middle fossa approach. The detailed description of the surgical technique and the large serie of patients make this article an excellent reference for otologic surgeons opting to use this approach.

In spite of this, the middle fossa approach technique was described in 14 patients with similar results after a follow up of 6-45 months in a previously study published by our group [2]. It was observed that the use of a neurodrill to create the bone bed makes this approach safer and easier, shortening the operative time and reducing the risk of damage to the dura mater and sigmoid sinus when compared with a classic otologic drill. With respect to the audiologic outcomes, as You et al. mention, we didn't observe any difference between the three possible approaches used for Bonebridge implantation, reporting an average functional gain of $33.46 \mathrm{~dB}$ [3], comparable to what has been reported in the literature $[4,5]$.

We agree with the conclusions of You et al. [1], and actually we consider this technique as a novel safe approach especially in patients where a classic presigmoid approach is not feasible. Furthermore it is technically easy and reproducible, with lower rate of complications and short surgical time. For all these reasons we believe that this approach could be the first choice technique for Bonebridge implantation, but further studies with larger series are needed to confirm our hypothesis.

\footnotetext{
* Correspondence: claudio.carnevale.orl@gmail.com

Otolaryngology Head and Neck Surgery Department, Son Espases University Hospital, Carretera Valldemosa, 79. 07210 Servicio ORL, Palma de Mallorca,
} Islas Balears, Spain

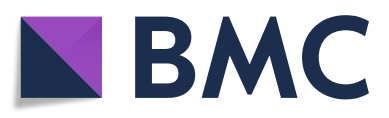

(c) The Author(s). 2019 Open Access This article is distributed under the terms of the Creative Commons Attribution 4.0 International License (http://creativecommons.org/licenses/by/4.0/), which permits unrestricted use, distribution, and reproduction in any medium, provided you give appropriate credit to the original author(s) and the source, provide a link to the Creative Commons license, and indicate if changes were made. The Creative Commons Public Domain Dedication waiver (http://creativecommons.org/publicdomain/zero/1.0/) applies to the data made available in this article, unless otherwise stated.
Acknowledgements

Not applicable.

\section{Authors' contributions}

PLS-E is the author of most of surgeries. MT-B, T-PG and CC have performed several surgeries and EE is the resident that helped to write the article and review the data published in the literature. All authors read and approved the final manuscript.

\section{Funding}

No funding has been received.

Availability of data and materials Not applicable.

Ethics approval and consent to participate Not applicable.

\section{Consent for publication}

Not applicable.

\section{Competing interests}

The authors declare that they have no competing interests.

Received: 23 August 2019 Accepted: 21 September 2019

Published online: 05 November 2019

\section{References}

1. You P, Siegel LH, Kassam Z, Hebb M, Parnes L, Ladak HM, et al. The middle fossa approach with self-drilling screws: a novel technique for Bonebridge implantation. J Otolaryngol Head Neck Surg. 2019;48:35.

2. Carnevale C, Tomás-Barberán M, Til-Pérez G, Sarría-Echegaray P. The Bonebridge active bone conduction system: a fast and safe technique for a middle fossa approach. J Laryngol Otol. 2019;133:344-7.

3. Carnevale C, Til-Pérez G, Arancibia-Tagle DJ, Tomás-Barberán MD, SarríaEchegaray PL. Hearing outcomes of the active bone conduction system Bonebridge in conductive or mixed hearing loss. Acta Otorrinolaringol Esp. 2019;70:80-8.

4. Rivas JA, Rincón LA, Garcia L, Rivas A, Tamayo C, Forero VH. Implantes auditivos de conducción ósea percutáneo, transcutáneo: comparación. Acta Otorrinolaringol Cir Cabeza Cuello. 2013;41:17-24.

5. Manrique M, Sanhueza I, Manrique R, de Abajo J. A new bone conduction implant: surgical technique and results. Otol Neurotol. 2014;35:216-20

\section{Publisher's Note}

Springer Nature remains neutral with regard to jurisdictional claims in published maps and institutional affiliations. 